\title{
THE WORKLOAD OF THE EUROPEAN COURT OF HUMAN RIGHTS: A BACK-DOOR TO BECOMING A CONSTITUTIONAL COURT OF EUROPE
}

\author{
DAMJAN GROZDANOVSKI*
}

\begin{abstract}
The workload of the European Court of Human Rights has been one of its main concerns, and having in mind that justice delayed is justice denied - it has been justifiably so. In order to deal with the backlog of pending cases before the Court the Convention mechanism has been subject to change on several occasions, with the first significant change occurring in 2010. It is undisputed that these changes affected the way in which the Court deals with cases, but have they also affected the very nature of the Court? The aim of this article is to provide an overview of these changes, and an analysis of the effects that these changes had on the nature of the Court and on the protection of human rights in Europe.
\end{abstract}

\section{INTRODUCTION}

Since its establishment in 1959, the European Court of Human Rights (the Court) played a central role in the development of human rights in Europe. For example, the Court has, through its case law, extended the scope of the inviolable right to life even to cases of legal deportation of foreigners to their home country where death penalty can be executed, ${ }^{1}$ and sanctioned the participation of European states in the CIA's secret rendition operations as contrary to the prohibition of torture. ${ }^{2}$ This was made possible by the applications of individuals lodged with the Court, with which these individuals complained of a certain action of a member State. These individual applications enable the Court to protect human rights in individual cases, while at the same time to set human rights standards applicable in all Council of Europe member States. Because of these reasons, the right to individual application has been repeatedly placed in the centre of the European Convention on Human Rights (ECHR) mechanism. ${ }^{3}$

It is indeed the right to individual application, as enshrined in Article $34 \mathrm{ECHR}$, which differentiates the European Court of Human Rights from most international courts. ${ }^{4}$ The fact that any person claiming to be the victim of a violation by a Council of Europe member State can complain to the Court, defined the nature of this Court as a true human rights court.

However, it is unlikely that anyone expected that this very same right to individual application, with time would become the main obstacle for the proper functioning of the

\footnotetext{
*Attorney at law from Skopje, LLM European Business Law, Lund University. Contact at damjan@ckr.mk

${ }^{1}$ Bader and Kanbor v. Sweden App no 13284/04 (ECtHR, 8 November 2005), paras 45-46.

${ }^{2}$ El-Masri v. Macedonia App no 39630/09 (ECtHR, 13 December 2012), para 218.

${ }^{3}$ Izmir Declaration (27 April 2011), para A (1); Interlaken Declaration (19 February 2010), para 1; Brighton

Declaration (21 April 2012), para 13; Brussels Declaration (27 March 2015), para 1.

${ }^{4}$ Other examples are the Court of Justice of the European Union, where preliminary references greatly outnumber direct actions, and the ECOWAS Court.
} 
Court. With pending application steadily rising since the Court started to work as a fulltime institution in 1998, they reached their peak with 160.200 pending cases in $2011 .^{5}$ At this time each application had to wait at least a year before the Court proceeded with the initial examination of the case. This was an obvious sign that the Convention mechanism required change - and all concerned parties agreed that this was necessary. However, there were different views as to what these changes should be and how they should be implemented.

The first clash of these views occurred at the beginning of the new century, with discussions taking place both inside and outside of the Council of Europe. On one side of this clash was itself the President of the Court at that time, who encouraged the idea that the Court should concentrate its efforts on decisions of 'principle', have a more 'constitutional' role and promote general instead of individual justice. ${ }^{6}$ The advocates of these views hoped for and actively supported 'a constitutional future for the European Court of Human Rights.'

On the other side of the spectrum were the supporters of individual justice, most notably the NGOs, but also scholars, who criticised attempts to 'obstruct individuals' redress for human rights violations ${ }^{8}$ and to undermine the fundamental right to individual petition. ${ }^{9}$ As mentioned above, even supporters of individual justice did not oppose change in the Court's system, however they feared that with the changes, as they were proposed, the Court would lose its trait, that is, it would no longer offer practical, tangible and concrete redress to the individual, and instead would turn to abstract and general justice - already specific for many, if not all bodies of international law. Overall, the early years of the new century seemed to be a crucial period for the future of the Court.

In reality, ever since the entry into force of Protocol 11 to the ECHR, the Court has had a dual function. In the eyes of the individual, it was as a court of last resort which can provide individual relief. After Protocol No. 11 to the ECHR, the right to individual application became fully institutionalised ${ }^{10}$ and could be seen as the motor of the enforcement machinery under the Convention. ${ }^{11}$ As mentioned above, all High Level Conferences on the future of the Court have, already in their first paragraphs, stressed the importance of the right to individual application. Even the Court itself stated that it primarily fulfils its task of ensuring the observance of the engagements undertaken by the member States by providing individual relief. ${ }^{12}$ Having this in mind, first and foremost the task of the Court, before the changes came into effect in 2010, was to provide individual justice.

\footnotetext{
${ }^{5}$ Press release ECHR 312, 24 October 2013.

${ }^{6}$ Luzius Wildhaber, 'The European Court of Human Rights in action' (2004) No. 21 Ritsumeikan Law Review, 91

${ }^{7}$ Luzius Wildhaber, 'A constitutional future for the European Court of Human Rights?' (2002) 23 Human Rights Law Journal, 161-165.

8 Amnesty International Press Release, European Court on Human Rights: Imminent reforms must not obstruct individuals' redress for human rights violations, 24 April 2004.

${ }_{9}^{9}$ Marie-Aude Beernaert, 'Protocol 14 and New Strasbourg Procedures: Towards Greater Efficiency? And at What Price?' (2004) 5 European Human Rights Law Review, 544-57.

${ }^{10}$ Luzius Wildhaber, 'Rethinking the European Court of Human Rights' in Jonas Christoffersen and Mikael R Madsen (eds), The European Court of Human Rights between Law and Politics (OUP 2011) 208.

${ }^{11}$ Ed Bates, The Evolution of the European Convention on Human Rights - From its Inception to the Creation of a Permanent Court of Human Rights (OUP 2010), 149.

12 Djokaba Lambi Longa v the Netherlands App no 33917/12, (ECtHR, 9 October 2012), para 58.
} 
However in a more profound sense, it was also a constitutional court. ${ }^{13}$ In this regard, even in the first years of its functioning as a full-time institution, the Court has built a precedent-based jurisprudence, thereby setting Pan-European human rights standards. ${ }^{14}$ The Court also frequently applied in its judgments balancing and proportionality tests, characteristic of many constitutional courts. ${ }^{15}$ In addition, the Court has stated its judgment do only provide individual redress, but they also serve to 'elucidate, safeguard and develop the rules instituted by the Convention thereby contributing to the observance ... of the engagements undertaken' by the member States ${ }^{16}$ and that the Court's role 'cannot be converted into providing individualised financial relief in repetitive cases arising from the same systemic situation'. ${ }^{17}$

The institutional debate within the Council of Europe was of course much less intense, as it was suppressed by the urgent need for reform. In this regard, in 2003, the Committee of Ministers appointed the Steering Committee for Human Rights (CDDH) to draft a reform proposal to 'assist the Court in carrying out its functions' and to reflect 'on the various possibilities and options' to ensure 'the effectiveness of the Court in the light of this new situation'. ${ }^{18}$ The CDDH came up with concrete solutions and thus, the first significant change in this regard was adopted in May 2004 and effectuated in June $2010 .{ }^{19}$ Other changes followed, of which the most recent one entered into force in August $2018 .{ }^{20}$ On the other hand, the institutional supporter of the Court's role as guarantor of individual justice was the Parliamentary Assembly of the Council of Europe, which has scrutinised and at times, as shall be seen below, criticised these changes, seeing them as a hindrance to the right to access to court.

The changes came in many different forms - mostly as Protocols to the ECHR, but also through case law of the Court, as well as changes to the Rules of Court. The latter were particularly convenient having in mind that they are adopted by the Plenary Court and can enter into force quickly, compared to the delayed entry into force of the Protocols, due to the lengthy, and even deliberately deferred ratification procedures in the Parliaments of the Council of Europe member States.

\footnotetext{
13 Alec Stone Sweet, 'On the Constitutionalisation of the Convention: The European Court of Human Rights as a Constitutional Court’ (2009) Faculty Scholarship Series, 2. See also, Loizidou v. Turkey App no 15318/89 (ECtHR, 23 March 1995), para 75.

${ }^{14}$ Steven Greer 'Constitutionalizing Adjudication under the European Convention of Human Rights' (2003), 23(3) Oxford Journal of Legal Studies, 405.

15 Inter alia, Robert Alexy, Constitutional Rights and Proportionality (2014) 22 Journal for Constitutional Theory and Philosophy of Law, 52-57.

${ }^{16}$ Guzaardi v Italy App no 7367/76 (ECtHR, 6 November 1980), para 86.

17 Wolkenberg and Others v Poland App no 50003/99 (ECtHR, 4 December 2007), para 76.

${ }^{18}$ Christina G. Hioureas 'Behind the Scenes of Protocol No.14: Politics in Reforming the European Court of Human Rights' (2006) Volume 24/Issue 2 Berkeley Journal of International Law

$<$ https://scholarship.law.berkeley.edu/cgi/viewcontent.cgi?referer=https://www.google.com/\&httpsredir= $1 \&$ article $=1320 \&$ context $=$ bjil $>$ accessed 29 May 2019.

${ }^{19}$ Protocol No. 14 to the ECHR - Point 2 of this Article.

${ }^{20}$ Protocol No. 16 to the ECHR - Point 5 of this Article.
} 
At first sight, these changes have had an outstanding effect - the backlog of pending cases was halved in just three years, with 151.600 pending cases in 2011 to 69.900 in $2014,{ }^{21}$ and further decreasing to 56.300 at the end of $2018 .{ }^{22}$ Looking at the statistics again, it sounds rather unnatural, to say the least, for a court to deal with more than 230.000 applications in a period of three years. In this regard, as it will be explained in the first part of point 2 of this Article, such reduction was mostly due to the vast number of dismissed cases.

These numbers are, however, only one side of the coin. The other side is the effect that these changes have had on the right to individual application and to the general perception of the Court as a guardian of human rights in Europe. It must not be overlooked that each case before the Court is often of paramount importance for the applicant and represents a last opportunity for the protection of its rights.

By analysing the effect these changes had on the nature of the Court, this Article argues that the unbearable caseload has given the Court a push to visibly (and hastily) tip over to the constitutional side of the individual - constitutional scale. Of course, the Court is limited by the framework of the ECHR, but it will be shown that it has used most of the constitutional instruments provided by the ECHR to the maximum.

This Article shall give an overview of the changes in the Convention mechanism, in order to prove that these changes, while dealing with the backlog of the Court, have changed its very nature. The first significant change - Protocol No. 14 to the ECHR, which entered into force on 1 June 2010, introduced among other things, the 'no significant disadvantage' admissibility criterion. Then, the development of the pilot judgment procedure through the Court's case law, and its inclusion on 21 February 2011 in Rule 61 of the Rules of Court gave the Court even more constitutional powers.

Added to this are the substantial changes of Rule 47 of the Rules of Court, which entered into force on 1 January 2014. This Rule deals with the procedural aspects of individual applications, and directly affects the right to individual application. In the end, the most recent change is presented, as effectuated by Protocol No. 16 to the ECHR, which entered into force on 1 August 2018 in relation to those Council of Europe member States which have ratified the Protocol. This Protocol prescribes the possibility for the Court to give advisory opinions on questions of principle relating to the interpretation or application of the rights and freedoms defined in the ECHR, which represents a significant addition to the Convention mechanism. All of these changes and their features are presented from the aspect of (un)intentionally altering the very nature of the Court.

\section{PROTOCOL NO. 14 TO THE ECHR - SINGLE JUDGE COMPETENCES AND NEW ADMISSIBILITY CRITERION}

This protocol to the ECHR was the first serious attempt to combat the Court's continuous build-up of pending cases. However, it faced difficulties even before entering into force although the final text of this Protocol was adopted in May 2004, it entered into force more

${ }^{21}$ ECHR - Analysis of Statistics 2017, 7.

${ }^{22}$ ECHR - Analysis of Statistics 2018, 6. 
than six years later, in June 2010. ${ }^{23}$ This long period even forced the Committee of Ministers to adopt a new provisional protocol, Protocol No. 14bis to the ECHR, which introduced only some of the changes prescribed in Protocol No. 14, namely, enabled a single judge to be able to reject manifestly inadmissible applications. This was seen as a quick way to significantly increase the Court's filtering capacity, until Protocol No. 14 enters into force. ${ }^{24}$ Nevertheless, Protocol No. 14bis did not have a significant impact, having in mind that it was in force for only less than 9 months - until Protocol No. 14 finally entered into force in June 2010 and gave effect to two significant changes in the Convention mechanism. Firstly, the competences of single judges were extended and secondly, a new admissibility criterion was introduced.

First, regarding the competences of single judges, a new Article 27 ECHR gave the power to a single judge to declare an application inadmissible or strike it out of the Court's list of cases, where such a decision can be taken without further examination. In accordance with the new Article 24 ECHR, a single judge in such a case is assisted by rapporteurs who function under the authority of the President of the Court. From a procedural aspect, this extension of powers of single judges was warranted and indeed provided instant relief for the Court's backlog problem by enabling single judges to swiftly dismiss manifestly illfounded applications, as presented below.

However, from substantive viewpoint it is clear that the decrease in the backlog of the Court was not due to fact that the Court delivered more judgments, but to fact that the Court was dismissing cases at a significantly faster rate. Looking at the statistics of the Court, ${ }^{25}$ at the end of 2011 there was a $42 \%$ decrease in delivered judgments compared to 2010, whereas 31\% increase in dismissed applications compared to 2010. Moreover, in 2011 and 2012 the Court decided only 1.551 and 1.678 application by judgment respectively - ironically in the years of the worst backlog, 2006-2010, the Court delivered more judgments! Even though the number of judgments per year eventually increased, it seems that in the first years of the entry into force of Protocol No. 14, the Court spent more time dismissing applications then creating case law. This was problematic, as increasing the number of dismissed applications at the expense of delivered judgments seems incompatible with the purpose of Protocol No. 14 presented in its Explanatory Report. ${ }^{26}$

The extension of the competences of single judges, were also problematic when viewed a substantive aspect. The rapporteurs assisting the single judge are non-judicial officers working in the Registry of the Court, ${ }^{27}$ but nevertheless they play a crucial role in the process of assessing if an application is admissible or inadmissible. Namely, the Court has been criticised for its process of assessing and categorising the many incoming applications: Periodically, a judge is

\footnotetext{
${ }^{23}$ With extended discussions in the parliaments of the member States, especially Russia. See, Jennifer Reiss 'Protocol No. 14 ECHR and Russian Non-Ratification: The Current State of Affairs' (2008) Vol. 22 Harvard Human Rights Journal, 293.

${ }^{24}$ Explanatory Report to Protocol No. 14bis to the ECHR (27 May 2009), 3.

${ }^{25}$ ECHR - Analysis of Statistics 2011, 6.

${ }^{26}$ Explanatory Report to Protocol No. 14 to the ECHR (13 May 2004), para 37.

27 Article 18A of Rules of Court from 1 August 2018.
} 
presented with a list containing single-sentence descriptions of new applications ${ }^{28}$ and on the basis of this sentence, the judge rubber-stamps the draft decision-letter, which is again prepared by the non-judicial Registry officer. ${ }^{29}$ This leaves the applicant with a decision-letter of inadmissibility without the judge even looking into the case-file. Such decision-letters often do not contain an explanation since there is no formal obligation for explanations. Furthermore, this decision is final without possibility to appeal, ${ }^{30}$ and the case file is destroyed in accordance with the internal procedures of the Court. Moreover, these decisions-letter are not published. ${ }^{31}$

Given the fact that 29,300 out of 43.100 cases in 2018 were identified as single-judge cases likely to be declared inadmissible, ${ }^{32}$ in around $70 \%$ of the cases the final decision was in substance taken by the Registry staff. The possibility for a judge to actually look into the case and amend the draft decision of the rapporteur is always, but in practice this is rarely the case.

Nevertheless, from June 2017, the Court, after officially announcing that the backlog has been eliminated, stated that it has changed the way in which it delivers single-judge decisions, and now instead of a decision-letter, applicants receive a decision of the Court sitting in single judge formation, which decision in many cases refers to specific grounds of inadmissibility. ${ }^{33}$ This basically implies that the Court was aware of its problematic practices, however it considered them necessary as long as the problem with the backlog existed. However, this pledge of the Court was not fully included in the revised Rules of Court applicable as of 1 August 2018, where Article 52A still leaves the possibility of the applicant being informed by letter.

The extension of the competences of single judges has indeed been justified by the development of the Court and it had an immediately visible effect on the backlog of the Court. However, the fact that the Court (over)used these competences to free itself of 230.000 applications in three years, even at the cost of reducing its judgment output, was not a step towards constitutional justice, but rather a step away from individual justice. It was the first sign of the Court's shift of attitude towards individual applications. Apart from this, the quick dismissal of cases through template-type decision-letters had a negative effect on the general perception of the Court and its legitimacy, which in turn affected the willingness of individuals to appeal to the Court. ${ }^{34}$

Secondly, Protocol No. 14 established the often criticised 'no significant disadvantage' admissibility criterion. The purpose of this new admissibility criterion is to enable a more

\footnotetext{
${ }^{28}$ Dinah Shelton, 'Significantly Disadvantaged? Shrinking Access to the European Court of Human Rights' (2016) 16 HRLR, 308.

${ }^{29}$ Ian Cameron, 'The Court and the Member States: Procedural Aspects' in Andreas Follesdal and others (eds), Constituting Europe: The European Court of Human Rights in a National, European and Global Context (CUP 2013), 33.

30 Article 27 (2) ECHR.

${ }^{31}$ Helena De Vylder, 'Stensholt v. Norway: Why single judge decisions undermine the Court's legitimacy' (Strasbourg observers, 28 May 2014) < https://strasbourgobservers.com/2014/05/28/stensholt-v-norway-whysingle-judge-decisions-undermine-the-courts-legitimacy-2/> accessed 17 March 2019.

32 ECHR - Analysis of Statistics 2018, 4.

33 Press release ECHR 180 (2017) from 01.06.2017.

34 Helena De Vylder, 'Stensholt v. Norway: Why single judge decisions undermine the Court's legitimacy' (Strasbourg observers, 28 May 2014) < https://strasbourgobservers.com/2014/05/28/stensholt-v-norway-whysingle-judge-decisions-undermine-the-courts-legitimacy-2/> accessed 17 March 2019.
} 
rapid disposal of so-called 'unmeritorious cases ${ }^{35}$ or 'insignificant violations ${ }^{336}$ and thus to allow the Court to concentrate on its central mission of providing legal protection of human rights at European level. The usage of the above cited words immediately suggests the lessening of the importance of the right to individual application, which the Court regard(ed) as a key component of the machinery for protecting the rights and freedoms set forth in the ECHR. ${ }^{37}$ Basically, the 'no significant disadvantage' criterion, as codified in Article 35 (3) (b), is an ECHR version of the de minimis non curat praetor principle.

Since Article 35 (3) (b) ECHR does not define what is insignificant disadvantage, the Court has, through its case law, given a such a definition. When it comes to financial disadvantage, the Court has stated that amounts around or less than 500 Euro are considered to be insignificant and do not warrant its consideration. ${ }^{38}$ Also, the Court has stated that it is not bound by the amount claimed as non-pecuniary damages, since this amount is often calculated by the applicants themselves on the basis of their own speculation. ${ }^{39}$

Apart from financial disadvantage, the Court has taken into consideration other types of disadvantage, such as personal ${ }^{40}$ or procedural ${ }^{41}$ disadvantage. Notwithstanding these criteria, the Court still has a lot of discretion in deciding what it considers to be (in)significant disadvantage for the purposes of Article 35 (3) (b).

Article 35 (3) (b) also prescribes two safeguard clauses. Namely, even when the disadvantage for the applicant is insignificant, the Court may still declare the case admissible on the basis that respect for human rights requires an examination on the merits or on the basis that the case has not been duly considered by a domestic tribunal.

Regarding the first safeguard clause, the Court examines whether the case involves question of a general character which would clarify the States' obligations under the Convention or induce the respondent State to resolve a structural deficiency. ${ }^{42}$ Paradoxically there is more case law which prescribes when this safeguard clause is not fulfilled. Namely, respect for human rights does not require an examination on the merits of an insignificant violation of the ECHR when:

- the Court has already established substantial case law on the issue at stake;43

- the Court has already addressed the problem in the respective country and acknowledged that it is systemic; 44

- the national law subject to complain by the applicant has been repealed, so that the complaint of the applicant is of historical interest only; 45

\footnotetext{
${ }^{35}$ Explanatory Report to Protocol No. 14 to the ECHR (13 May 2004), 14.

36 Nina Vasilyevna Shefer v. Russia App no 45175/04 (ECtHR, 13 March 2012), para 18.

${ }_{37}$ Mamatkulov and Askarov v. Turkey App no 46827/99 and 46951/99 (ECtHR, 4 February 2005), para 122.

${ }^{38}$ Kiousi v. Greece App no 52036/09 (ECtHR, 20 September 2011).

39 ibid.

40 Luchaninova v. Ukraine App no 16347/02 (ECtHR, 9 June 2011).

41 3 A.CZ s.r.o. v. the Czech Republic App no 21835/06 (ECtHR, 10 February 2011).

42 Korolev v. Russia App no 25551/05 (ECtHR, 1 July 2010).

${ }^{43}$ Bazelyuk v. Ukraine App no 49275/08, (ECtHR, 27 March 2012).

${ }^{44}$ Vasilchenko v. Russia App no 34784/02, (ECtHR, 23 September 2010), para 49.

${ }^{45}$ Ionescu v. Romania App no 36659/04, (ECtHR, 1 June 2010), paras 38-39.
} 
Having these principles in mind, it appears that the first safeguard clause would rarely apply to reasonable time complaints under Article 6 (1) ECHR against counties which are known for their unreasonable length of proceedings, since there would normally be substantial case law on that issue. ${ }^{46}$ These cases are a perfect example of what the Court considers to be 'unmeritorious cases'.

Regarding the second safeguard clause, a case will nonetheless be declared admissible if it has not been duly considered by a domestic court. This was included to ensure that the applicant's case has been heard at national level, that is, to ensure that individual justice was not denied. For the purposes of this Article, the Court considers a case to be duly considered by a domestic court if that court reviewed the applicant's case, regardless of whether it properly examined the applicant's claims of breaches of the rights enshrined in the ECHR. ${ }^{47}$ Additionally, minor imperfections do not imply that the case has not been 'duly' considered by a national court. ${ }^{48}$

Apart from setting a low threshold for what it considers to be a duly considered case, the Court further held that when 'an applicant alleges a violation of the ECHR by the last-instance judicial authority of the domestic legal system, the Court may dispense with the [second safeguard clause], ${ }^{49}$ whereas at times it simply did not apply this safeguard clause at all and went on to rejected the cases as inadmissible according to Article 35 (3) (b) without examining whether they were duly considered by a national court. ${ }^{50}$ All in all, the second safeguard clause proved to be ineffective partially because of its mild wording, but mostly because of the Court's restrictive interpretation. In fact, apart from clear-cut cases where there was no legal remedy available for the applicant, ${ }^{51}$ the Court has not given effect to the second safeguard clause.

This behaviour of the Court seems to be in line with Protocol No. 15 amending the ECHR, because when this Protocol enters into force, ${ }^{52}$ the second safeguard clause from Article 35 (3) (b) ECHR shall be deleted. This is done again with the aim of enhancing 'the effectiveness of the system, ${ }^{53}$ Nevertheless, since the second safeguard clause did not have a significant impact in practice, ${ }^{54}$ it can be expected that its deletion will also not cause

\footnotetext{
${ }^{46}$ Here referring to Italy and other Southern European countries. See, Giorgi v. Italy App no 23563/07, (ECtHR, 6 March 2012), para 61; Jovanovska and Others v. Macedonia App no 14001/13 and 22883/14 (ECtHR, 14 November 2017), para 13; Galović v. Croatia App no 54388/09 (ECtHR, 5 March 2013), para 75. See also, Dudek v. Germany App nos 12977/09, 15856/09, 15890/09, 15892/09 and 16119/09 (ECtHR, 23 November 2010).

47 Vincent Cecchetti v San Marino App no 40174/08 (ECtHR, 9 April 2013), paras 39-41. Even though in one earlier case, the Court had a different view, Flisar v Slovenia App no 3127/09 (ECtHR, 29 September 2011), para 28.

48 Janneke H. Gerards and Lize R. Glas, 'Access to justice in the European Convention on Human Rights system’ (2017) Vol. 35(1) Netherlands Quarterly of Human Rights, 21.

49 Galovic v Croatia App no 54388/09 (ECtHR, 17 September 2009), para 77.

50 Shtefan and Others v. Ukraine App no 36762/06 (ECtHR, 31 July 2014), paras 30-32.

51 Dudek v Germany (n 46). Also, in few more cases the Court has joined the examination of the second safeguard clause to the merits of the complaints, see Fomin v Moldova App no 36755/06 (ECtHR, 11 October 2011), para 20

52 Pending the ratification by Italy and Bosnia and Herzegovina. Chart of signatures and ratifications of Treaty 213 (Protocol No. 15 amending the ECHR) < https://www.coe.int/en/web/conventions/search-ontreaties/-/conventions/treaty/213/signatures?p auth=PIKIXLbw > accessed 18 March 2019.

${ }^{53}$ Explanatory Report to Protocol No. 15 amending the ECHR (CETS No. 213), para 23-24.

${ }_{54}$ Antoine Buyse, 'Significantly Insignificant? The Life in the Margins of the Admissibility Criterion in Article 35
} 
turmoil. However, it remains to be seen whether the Court will view its deletion as encouragement to use Article 35 (3) (b) ECHR more frequently.

Having in mind the broad definition of 'insignificant disadvantage' as well as the narrow definition of the two safeguard clauses, it is unsurprising to see different cases being declared inadmissible under this Article. Two cases are shall be presented as example in this regard.

The first case ${ }^{55}$ involves an individual who was not wearing his seat belt and insulted the police, thereby receiving a fine of $€ 150$. This individual brought the case before the Court complaining that his freedom of expression and his right to fair trial have been violated. The Court declared the case inadmissible according to Article 35 (3) (b) ECHR by stating the amount in question did not represent a particular hardship for the applicant and moreover that the subject matter of the complaint did not give rise to an important matter of principle. Both of these conclusions are more or less obvious from the facts of the case.

The second case,${ }^{56}$ involves criminal proceedings against an individual for organising an international prostitution ring, trafficking in human beings committed as part of an organised gang, and criminal conspiracy. The proceedings before the national courts concluded with a partial charge sentencing the individual to six years' imprisonment, a fine of 10,000 Euro and a five-year exclusion order from certain departments of France. ${ }^{57}$ The individual brought the case before the Court complaining of discrimination in the enjoyment of his right to a fair trial, as well as infringement of the right to an effective remedy, because he was not offered a common procedural safeguard (video recording of interviews at the investigating judge's office). The French Code of Criminal Procedure had provisions which established that this safeguard shall not apply where the investigation concerns organised crime - and this condition was fulfilled in the present case.

During the proceedings, the Conseil constitutionnel declared these provisions unconstitutional stating that they were discriminatory, and it was exactly the applicant's complaints which motivated the Cour de cassation to refer a request for preliminary ruling on the constitutionality of these provisions to the Conseil constitutionnel. Yet, the Conseil constitutionnel abrogated this provisions ex nunc, which basically led to the applicant being sentenced to prison in a procedure in which certain decisions have been based on unconstitutional provisions.

The Court declared the application inadmissible pursuant to Article 35 (3) (b) ECHR, stating that, even if there was discrimination, it did not have any significant impact on the exercise of his rights or on his personal situation. ${ }^{58}$ However, as pointed out in the partly dissenting opinion of one judge, ${ }^{59}$ the case was not straightforward and involved arguable claims which deserved to be examined by the Court on the merits. Namely, the Court had to determine whether the applicant's right to an effective remedy has been violated, because

$\$ 3$ (b) ECHR' (2013) Liber Amicorum for Leo Zwaak, $11<$ http://ssrn.com/abstract=2244283 $>$ accessed 18 March 2019.

55 Sylka v. Poland App no 19219/07 (ECtHR, 3 June 2014).

56 Nikolov v. France App nos 70474/11 and 68038/12 (ECtHR, 10 November 2016). Note that there are two concurring and one dissenting opinion regarding the admissibility of the case.

${ }^{57}$ Interestingly one of the departments was Bas-Rhin, where the Court is located.

${ }^{58}$ Conversely, see Luchaninova $v$. Ukraine (n 40), where the Court found that a conviction, even though it was not accompanied by a penalty, did have a negative effect on the personal situation of the applicant.

${ }^{59}$ Partly dissenting opinion of Judge Mits in Nikolov $v$. France (n 56). 
in the present case this right was crucial for the proper protection of the applicant's rights within the domestic legal system. ${ }^{60}$ The Court, however, skipped this step and declared the whole case inadmissible.

These cases best illustrate the wide application of this Article and to some point the discretion the Court enjoys when applying it, although there are cases in which the Court has taken into consideration a variety of factors, ${ }^{61}$ as well as assessed the applicant's subjective perceptions in addition to what is objectively at stake in a particular case. ${ }^{62}$ The broad interpretation of 'insignificant disadvantage' and the low threshold for the safeguard clauses, or even their non application, seem to confirm the fears of the Parliamentary Assembly of the Council of Europe that the new admissibility criterion is 'vague, subjective and liable to do the applicant a serious injustice'. ${ }^{63}$ It gives the Court a second chance to dismiss an application which satisfies all the other admissibility criteria, and save resources on cases which it considers not to deserve its attention. This criterion represents another tool in the Court's arsenal for reducing its backlog and enabling itself to focus on decisions of principle. This would have been perfectly justified, had the Court established clear rules and applied them consistently, thereby providing applicants with legal certainty, much needed in times of change.

\section{RULE 61 OF THE RULES OF COURT - PILOT JUDGMENT}

In practice, when an application reaches the Court and contains all the needed information it is firstly classified in three categories: clearly inadmissible, repetitive or non-repetitive. Clearly inadmissible cases are dealt by single judges as explained in the first part of point 2 of this Article, whereas repetitive and non-repetitive cases are dealt by three judge Committees or seven judge Chambers, respectively.

Having in mind that the category of clearly inadmissible cases, to which are placed by far the most cases, ${ }^{64}$ no longer constitutes a problem for the Court, the next on the agenda was the category of repetitive cases. These repetitive cases in 2018 constituted 29.350 out of 56.350 pending cases. ${ }^{65}$ The Court found a solution for dealing swiftly with these cases through its case law - the pilot judgment procedure.

The case which served as the basis for the official introduction of the pilot judgment procedure in Article 61 of Rules of Court, concerned a certain Polish legislative scheme, affecting around 80.000 people, which violated the right to property as enshrined in Article 1 of Protocol No. $1 .^{66}$ Moreover, there were 167 applications pending at that time before the Court regarding the very same issue. ${ }^{67}$ The solution of the Court in this case was based on Article 46 ECHR and involved the obligation of the Council of Europe member States to

\footnotetext{
${ }^{60}$ The dissenting opinion went on to conclude that there was no violation of the right to an effective remedy.

61 Živić v. Serbia App no 37204/08 (ECtHR, 13 September 2011), para 46.

${ }^{62}$ Inter alia, Korolev v. Russia App no 25551/05 (ECtHR, 1 July 2010) .

${ }^{63}$ Parliamentary Assembly of the Council of Europe, Opinion No. 251 (2004), para 11.

${ }^{64}$ Here referring to new cases. The majority of pending cases are repetitive cases.

${ }^{65}$ See, ECHR - Analysis of Statistics 2018, 6. The reason that there is a high number of new clearly inadmissible cases and a low number of pending clearly inadmissible cases is the swift dismissal of clearly inadmissible cases by a single judge. See that there were 40.023 inadmissible cases decided in 2018 , compared to 2.738 judgments delivered in the same year.

${ }^{66}$ Broniowski v. Poland App no 31443/96 (ECtHR, 22 June 2004).

67 ibid, para 193.
} 
adopt in their domestic legal order general and/or individual measures which would put an end to the violation found by the Court and to redress the effects of the violation as much as possible. This was particularly suitable in cases where the violation originates from a systemic problem connected with the malfunctioning of domestic legislation, since such systemic problems generate lot of complaints which would eventually end up before the Court in Strasbourg ie would increase the caseload of the Court. ${ }^{68}$

This case was followed by other cases which dealt with a systemic problem affecting many persons. ${ }^{69}$ This led to the need, as stated in point $7 \mathrm{~b}$ ) of the Interlaken Declaration ${ }^{70}$ to 'develop clear and predictable standards for the pilot judgment procedure as regards selection of applications, the procedure to be followed and the treatment of adjourned cases.' Having this in mind, the Court on 21 February 2011 inserted Rule 61 in its Rules of Court, which regulates the pilot-judgment procedure. Apart from the established principles in its case law, the Court added the possibility to specify the time in which the general remedial measures are to be adopted ${ }^{71}$ and the possibility to adjourn the examination of all similar applications during this time. ${ }^{72}$ As any final Court's decision, the pilot judgment is transmitted to the Committee of Ministers, which supervises its execution. In this regard, the Committee of Ministers annually issues a decision which notes the specific actions the state undertook in order to comply with the pilot judgment. ${ }^{73}$

The Court should only use the pilot judgment procedure in relation to cases which involve many individuals affected by a specific and distinct action of the state. In this way, the country would be required to regulate a specific area with concrete measures, and furthermore individuals would have no doubt whether their case falls within the scope of the pilot judgment or not. On the other hand, pilot judgment in cases which involve general and undefined structural deficiencies, for example non-enforcement of domestic judgments ${ }^{74}$ or excessively long court

proceedings ${ }^{75}$ prove to be inefficient, since countries are unable or unwilling to comply with them. ${ }^{76}$

A top example of an inefficient pilot judgment is the Ivanov $v$ Ukraine case, ${ }^{77}$ which concerned the systemic problem of non-enforcement of domestic decisions in Ukraine. With this pilot judgment the Court ordered Ukraine to set up, within one year from the date

\footnotetext{
68 ibid, paras 190-192.

${ }^{69}$ Hutten-Czapska v. Poland App no 35014/97 (ECtHR, 19 June 2006); Suljagić v. Bosnia and Herzegovina App no 27912/02 (ECtHR, 3 November 2009).

${ }^{70}$ Interlaken Declaration - High Level Conference on the Future of the European Court of Human Rights,

19 February 2010.

${ }^{71}$ Rule 61, para 4 of Rules of Court.

72 ibid Rule 61, para 6.

${ }^{73}$ For example, the measures of Belgium to comply with the pilot judgment in the case W.D. v. Belgium App no 73548/13 (ECtHR, 6 September 2016) were examined on the 1302nd meeting, 5-7 December 2017 (DH) which produced the document CM/Notes/1302/H46-5 from. The assessment was carried out again on the 1324th meeting, 18-20 September 2018 (DH), which produced the document CM/Notes/1324/H46-3.

${ }^{74}$ Ivanov v. Ukraine App no 40450/04 (ECtHR, 15 October 2009).

75 Gazsó v. Hungary App no 48322/12 (ECtHR, 16 July 2015).

${ }^{76}$ Eline Kindt, 'Non-execution of a pilot judgment: ECtHR passes the buck to the Committee of Ministers in Burmych and others v. Ukraine' (Strasbourg observers, 26 October 2017)

$<$ https://strasbourgobservers.com/2017/10/26/non-execution-of-a-pilot-judgment-ecthr-passes-the-buckto-the-committee-of-ministers-in-burmych-and-others-v-ukraine/> accessed 18 March 2019.

${ }^{77}$ Ivanov v. Ukraine (n 74).
} 
on which the judgment becomes final, an effective domestic remedy capable of securing adequate and sufficient redress for the non-enforcement or delayed enforcement of domestic decisions, in line with the Convention principles. From the outset, it seems that the structural problem had deep roots within Ukraine's legal system, whereas the measure requested has been formed broadly. ${ }^{78}$ Because of this Ukraine was not able / willing to act in accordance with the instructions, and cases before the Court continued to pile up, until the situation culminated with the Burmych and Others $v$ Ukraine cases. ${ }^{79}$

In what seems to be one of the most controversial judgments, the Court decided to strike 12,148 applications out of its list of cases 'at a single blow'. By stating that it discharged its function under Article 19 ECHR with the Ivanov pilot judgment, the Court decided to transmit these applications to the Committee of Ministers in order for them to be dealt with in the framework of the general measures of execution of the Ivanov judgment. This led to stunning statistics for 2017 - 15,595 applications decided by judgment, that is, a $709 \%$ increase compared to $2016 .{ }^{80}$ Additionally, the Court went even further by stating that in future similar applications, the applicants shall be considered 'victims' within the meaning of Article $34 \mathrm{ECHR}^{81}$ and the Court would in turn transmit their applications directly to the Committee of Ministers, except the inadmissible ones. ${ }^{82}$ Thus, the Court appears to become a filtering body for the Committee of Ministers. This dramatically affected not only the statistics, but also individual human rights.

In this regard, the 41-paragraph joint dissenting opinion of seven judges in the case criticises the majority using unusually strong words, starting with 'The present judgment has nothing to do with the legal interpretation of human rights.' and ending with 'This judgment is without legal basis in the Convention, it throws thousands of desperate people into a legal limbo and undermines the protection of human rights of the Convention - we most emphatically dissent.'

Particularly problematic in this case is the disposal of human rights claims in a summary manner without individual assessment, as well as the transfer of present and future cases to the Committee of Ministers. This undermines the human rights protection at European level, since it replaces judicial protection of individual human rights with nonenforceable decisions of a political body. This does not seem to be in line with Protocol No. 14 to the ECHR, as this Protocol empowered the Committee of Ministers only to supervise the execution of the Court's judgments and to initiate infringement proceedings before the Court against any State refusing to comply with a judgment. ${ }^{83}$ On the other hand, this Protocol empowered committees of three judges to rule on the merits of a repetitive application. ${ }^{84}$ A legitimate question to ask is why the Court did not make use of these competences in the present case - it may not have been as efficient as striking out more than 12,000 cases, but it sure would have been much more suitable in terms of individual human

\footnotetext{
${ }^{78}$ For a well-formed and concrete measure see, Suljagic v. Bosnia and Herzegovina App no 27912/02 (ECtHR, 3

November 2009). Also see, M.C. and Others v. Italy App no 5376/11 (ECtHR, 3 September 2013)

${ }^{79}$ Burmych and Others v. Ukraine App no 46852/13 et al. (ECtHR, 12 October 2017).

80 Analysis of statistics 2017, 6.

${ }^{81}$ Burmych and Others (no 79), para 203.

82 ibid, para 221.

83 Article 46 ECHR.

${ }^{84}$ Article 28 ECHR.
} 
rights protection. Thus, this action of the Court seems to distort to the well-established and unique system of judicial protection of individual human rights at European level.

Of course, one argument in favour of the majority decision could be that the Court has already done everything in its power, ${ }^{85}$ therefore it was time to ease the burden on itself and transfer the cases to the Committee of Ministers, which could solve them in a more political manner. However the Court itself prevented the use of this argument, by stating that it would be 'appropriate to reassess the situation within two years of the delivery of the present judgment'. ${ }^{86}$ By doing so, the Court seems to have provided itself with only momentary judicial relief and convenience.

Another striking feature of the reasoning of the Court in this judgment is the use of the word 'burden ${ }^{87}$ when in essence referring to the duty of the Court to hear individual applications. It seems that what once the Court regarded as a central feature of the control machinery of the ECHR, has suddenly become an unnecessary burden on the Court. Without going into details as to the context in which this was said, potential applicants definitely viewed it as an off-putting message. ${ }^{88}$

Again, central for the Court when applying the pilot judgment procedure are the notions of efficiency, as well as 'going beyond the sole interests of the individual applicant'. ${ }^{89}$ Similarly as the 'no significant disadvantage' criterion, the pilot judgment procedure enables to Court to focus on significant cases which warrant consideration on the merits, instead of repetitive cases, which only require the application of already established rules and principles. It enables the court to contribute to general justice, leaving individual justice to other national or international bodies. And again, similarly as the 'no significant disadvantage' criterion, it is the view of the author that this would have been perfectly justified, had the Court applied it in a way which would ensure minimum individual justice and had the Court not at times (mis)used this procedure to free itself from its Convention-prescribed duties.

\section{REVISED RULE 47 OF RULES OF COURT - CONTENS OF AN INDIVIDUAL APPLICATION}

The revision of Rule 47 of Rules of Court, which deals with the contents of an individual application and which entered into force on the 1 January 2014, was another of the methods to 'facilitate filtering" ${ }^{90}$ of cases brought before the Court. The introduction of strict formal admissibility rules complemented the system of substantive inadmissibility which enabled single judges to dismiss manifestly ill-founded cases, as explained in the first part of point 2 of this Article. The main difference between these two types of admissibility rules is that the individual applications which do not comply with the formal rules, as shall be seen below, are outright dismissed without being allocated to any of the Court's judicial formations ie are dismissed by the Registrar of the Court.

\footnotetext{
85 The Court had 6,000 identical judicial decisions against Ukraine, and approximately 12 million Euro in just satisfaction awards against Ukraine.

${ }^{86}$ Ivanov v. Ukraine (n 74), para 223.

87 ibid, para 174, para 201.

${ }^{88}$ In 2018 there was a decrease of 32\% of new applications compared with 2017, Analysis of statistics 2018, 4

${ }^{89}$ Broniowski v. Poland App no 31443/96 (ECtHR, 22 June 2004) para 36.

${ }^{90}$ Report on the implementation of the revised rule on the lodging of new applications $02 / 2015,1$.
} 
Before 1 January 2014 the Court looked into the nature of the formal errors and the applicants not complying with the formal rules were notified of their errors and were often given extension of the six-month time limit. ${ }^{91}$ This was in accordance with the view of the Court that 'the rules of admissibility must be applied with some degree of flexibility and without excessive formalism'. ${ }^{2}$

The Court's change of attitude was best visible when it dismissed an application submitted on 21 May 2014, and used it to stress the strict examination and application of the revised Rule 47, as well as the six-month time period for lodging an application as prescribed by Article 35 (1) ECHR. ${ }^{93}$ Such change of attitude, especially after the Court has shown leniency towards the formal rules, was followed with a significant rise in the number of dismissed applications. Since exceptions to this rule are practically non-existent, except for requests for interim measures, incomplete applications are declared inadmissible without even being allocated to any of the Court's judicial formations. ${ }^{94}$ Namely, 12,191 applications or almost a quarter of all the applications lodged in 2014, failed to comply with the revised rule and were thus disposed of administratively. ${ }^{95}$ Moreover, this number does not include complaints submitted on a different form than the one provided on the Court's website, since those complaints were not even considered to be applications. Again, the efficiency gains were the centre of attention. Nevertheless, since applications disposed of administratively are destroyed and never published or reviewed, one can only wonder how serious a breach of human rights those 12,191 application or other letters might have complained of.

As time passes and individuals and lawyers get familiar with the procedural rules of the Court, ${ }^{96}$ the number of applications disposed of administratively decreases - in 2016 there was a $35 \%$ decrease compared to $2015 .^{97}$

In this part, suffice it to say that establishing a system of formal rules to which every application would be subjected to, was indispensable to ensure the proper functioning of the Court. Nevertheless, the fact that the newly established system did not have a sufficiently long transitional period and the sudden change of attitude make questionable the way in which it had put into effect such a system.

Speaking of procedural admissibility rules, it is important to note that when Protocol No. 15 amending the ECHR enters into force it shall reduce the time for submitting an application to the Court from six to four months from the date on which the final national decision was taken. ${ }^{98} \mathrm{~A}$ transitional provision which provides that this new rule shall enter into force six months after Protocol No. 15 enters into force and furthermore shall not apply to applications in respect of which the final national decision was taken prior to the date of

\footnotetext{
91 Janneke H. Gerards and Lize R. Glas, 'Access to justice in the European Convention on Human Rights system’ (2017) Vol. 35(1) Netherlands Quarterly of Human Rights, 11.

92 İlhan v. Turkey App no 22277/93 (ECtHR, 27 June 2000), para 51.

${ }_{93}$ Malysh and Ivanin v Ukraine App nos 40139/14 and 41418/14 (ECtHR, 9 September 2014).

94 ibid.

${ }^{95}$ See Report (n 90).

${ }^{96} \mathrm{ibid}, 3$.

${ }^{97}$ ECHR - Analysis of Statistics 2016, 4.

98 Article 4 of Protocol No. 15 amending the ECHR.
} 
entry into force of this new rule, ${ }^{99}$ will hopefully mitigate the negative effects that any change of the procedural admissibility rules has on the right to individual application. Nevertheless, this change represents another significant step forward in the continuous efforts to introduce stricter procedural admissibility rules, which inevitably affect the right to individual application.

\section{PROTOCOL NO. 16 TO THE ECHR - ADVISORY OPINIONS}

Protocol No. 16 to the ECHR, which entered into force on 1 August 2018 in relation to those Council of Europe member States which ratified it, ${ }^{100}$ gives power to the Court to give advisory opinions on questions of principle relating to the interpretation or application of the rights and freedoms defined in the ECHR. This is the most recent change in the Convention mechanism which aims to improve the 'long-term effectiveness of the ECHR control mechanism'. ${ }^{101}$ Even when discussing the possible extension of the Court's advisory jurisdiction, the Court hoped that the procedure would be designed in a manner so as to enable it to decrease its workload, ${ }^{102}$ firstly by strengthening its constitutional role, ${ }^{103}$ and secondly by reinforcing the domestic courts' role in implementing the Convention. ${ }^{104}$ Thus, this change in the Convention mechanism can be seen as the latest attempt to reduce the caseload and at the same time enable the Court to focus on important questions of principle.

In this regard, the first request for advisory opinion came from the French Cour de cassation, concerning surrogacy, which the Court swiftly accepted. ${ }^{105}$ Looking way in which the French Cour de cassation formed the questions, there is an immediate resemblance of this procedure with the preliminary reference procedure before the Court of Justice of the EU. The advisory opinion which came from the Court, ${ }^{106}$ however, did not resemble a judgment under Article 267 TFEU, as it did not engage with the facts of the case as much, ${ }^{107}$ nor with the arguments submitted by the participants in the proceedings. ${ }^{108}$

On the other hand, and surprisingly so, the answer of the Court was quite limited to the context of the case pending before the requesting court. ${ }^{109}$ Apart from the (already established) ${ }^{110}$ finding of the Court that an absolute impossibility of recognition of the relationship between a child born through a surrogacy arrangement entered into abroad and the intended mother would violate the Convention, ${ }^{111}$ the Court does not seem to set any

\footnotetext{
99 ibid, Article 8, para 3.

100 Albania, Armenia, Estonia, Finland, France, Georgia, Lithuania, San Marino, Slovenia, Ukraine. It shall enter into force in relation to the Netherlands on 01/06/2019 - Chart of signatures and ratifications of Treaty 214 (Protocol No. 16 to the ECHR) < https://www.coe.int/en/web/conventions/search-on-treaties/Lconventions/treaty/214/signatures?p auth=EzUkBjcI $>$ accessed 18 March 2019

${ }^{101}$ Explanatory Report to Protocol No. 16 to the ECHR (2 October 2013), 1.

102 Reflection paper on the proposal to extend the court's advisory jurisdiction, ECtHR 2013, para 15.

103 ibid, para 5.

104 ibid, para 16. See also, Janneke Gerards 'Advisory Opinions, Preliminary Rulings and the New Protocol

No. 16 to the European Convention of Human Rights: A Comparative and Critical Appraisal' (2014),

Maastricht Journal of European and Comparative Law Vol 21 Issue 4, 632.

105 Press release ECHR 415 (2018) from 04 December 2018.

106 Advisory Opinion P16-2018-001 (ECtHR, 10 April 2019).

107 ibid, para 25.

108 ibid, para 34 .

109 ibid, para 36.

${ }_{110}$ Mennesson v France App no 65192/11 (ECtHR, 26 June 2014), paras 99-100.

111 ibid, para 42.
} 
Europe-wide surrogacy standard. Therefore, if the Court's competence to give advisory opinion is to be assessed by its first delivered opinion, it can be said that the Court itself refuses to use this competence to reinforce its constitutional role.

However, looking at the advisory opinion procedure from a more general aspect, central to it is the principle of subsidiarity, which was included in recital 3 of the Preamble of the ECHR through Protocol No. 15 to the ECHR. ${ }^{112}$ According to principle, national authorities are better placed than an international court to evaluate local needs and conditions, and it is the national courts which are primary obliged to protect the rights and freedoms enshrined in the ECHR. In this regard, it would have been very useful for the Court to use the first advisory opinion to provide national authorities with general principles or instructions as to how they should act, thereby reinforcing the principle of subsidiarity, as well as its constitutional role. On the contrary, if the Court only offers an opinion applicable to a specific situation as it did in its first advisory opinion, it risks making it comparable to actual cases before it, thereby making it redundant. For now, it remains to be seen whether the Court shall give more weight to this procedure in its future advisory opinions.

It seems that the advisory opinion procedure represents a concrete step in the process of constitutionalisaton of the Court, which the Court itself seems to support, ${ }^{113}$ even though in its first advisory opinion it has not acted accordingly. Nevertheless, the possibility for the Court to set Europe-wide human rights standard without having an individual application before it and

without actually solving a case, undoubtedly represents a major change in the Convention mechanism.

\section{CONCLUSION}

All of the above changes successfully managed to counter the far-reaching backlog problem of the Court - the Court proudly stated in 2017 that the backlog problem has been eliminated. However, the process to reform the Convention mechanism cannot be viewed in isolation.

On the contrary, a change in one part of the mechanism, inevitably affects the mechanism as a whole. In this regard, the changes presented in this Article have definitely altered the nature of the Court, for better or for worse. Nine years after the first change was put into effect, the Court deals with cases almost completely differently and furthermore, is perceived differently by individuals. This especially applies to the perception of the Court in the developing European countries where the Court used to be perceived as a Court of last resort which protects individual human rights and contributes to individual justice. For example, in 2018 there were 7.267 cases against Ukraine, out of which only 10 were declared admissible (around $0.1 \%) .{ }^{114}$

The Council of Europe, and the Court itself, decided that protection of human rights in Europe would be better carried out if the Court contributes to constitutional, general justice. Equipped with the powers to adopt pilot-judgments and deliver advisory opinions, while having the means to dispose itself of individual repetitive cases which do not contribute

\footnotetext{
112 However, the principle of subsidiarity has been developed and used by the Court long before its codification in the ECHR.

113 Reflection paper (n 102), para 5.

114 ECHR - Analysis of Statistics 2018, 59.
} 
to its case law, the main task of the Court now seems to be to ensure that 'administrative and judicial processes in member states effectively conform to pan-European Convention standards'. ${ }^{115}$ Therefore, it can be said that the Court now functions more as a Constitutional Court of Europe.

This does not in itself have a negative effect on the human rights situation in Europe. To this day, the Court still protects human rights and contributes to their development in Europe and will most certainly continue to do so. However, the way in which was this change happened can be questionable. As explained above, some of the measures were radical and were implemented in a short period of time, not allowing the public to get a grasp of the seriousness of the changes. Moreover, it seems that at times the Court's backlog problem has been used as an excuse to promote its constitutional function, which in turn was presented as an excellent way to counter the backlog problem, while improving the situation of human rights in Europe. Even though it is true that the constitutional role of the Court has contributed to both of these aims, it would have been much better if this process had been carried out more openly and steadily, instead of rushing to solve the backlog problem.

The problem with the Russian non-ratification of Protocol No. 14 for six years, proved that the Court was not yet on the brink of collapse, that is, it could still function, even though sluggishly, despite the great backlog. Therefore, there was no need to rush through the process, and risk undermining the unique system which took great effort to establish. Indeed, some of the actions of the Court in the last period have been rather rash and subject to criticism or even condemnation from members of the Court and the Council of Europe, not to speak outside of it.

Unlike the European Court of Human Rights whose nature seems to be implicit, certain judges of the Court of Justice of the EU have clearly stated that the CJEU is not a human rights court. ${ }^{116}$ With the European Court of Human Rights now taking a more constitutional function and distancing itself from cases which offer nothing more but individual redress, there is a possibility of legal vacuum in the protection of individual human rights in the so called repetitive cases. This was best visible in the Burmych cases, as well as in the unmeritorious cases referred to in the main part of the Article. Therefore, it is now up to the Council of Europe, and particularly the Committee of Ministers, to supervise the execution of judgements, especially pilot judgments, and to promote the principle of subsidiarity in accordance with which violations of rights enshrined in the ECHR should be sanctioned by the domestic courts. Also, national courts should be encouraged to refer to the case law of the Court more often and in that way protect the rights enshrined in the ECHR at national level. This is crucial for individual justice to be ensured in a changed European legal order, in which the Court plays a more constitutional role.

\footnotetext{
115 Steven Greer, 'Constitutionalizing Adjudication under the European Convention of Human Rights' (2003) 23(3) Oxford Journal of Legal Studies, 405.

116 Xavier Groussot, Nina-Louisa Arold Lorenz and Gunnar Thor Petursson, 'The Paradox of Human Rights Protection in Europe: Two Courts, One Goal' in Oddný Mjöll Arnardóttir, Antoine Buyse (eds), Shifting Centres of Gravity in Human Rights Protection (Routledge 2016) 19.
} 